2 St George IM Williams SMI, Silva PA. The stability of blood pressure in

Dunedin children: an eight vear longitudinal study. $N Z$ Med 7 1990;886:115-

3 Silva PA. The Dunedin multidisciplinarv health and development study: a fifteen

+ Stanton WR, Silva PA, Oei TPS. The origins and development of an addictive behaviour: a lompitudinal sudy of smoking. Dunedin: Dunedin Multidisciplinary Health and Development Research Unit, 1989.
Research Institute for Social Security, Social Insurance Institution, 00380(Helsinki, Finland) Paul Knekt, PHD, research officer

Antti Reunanen, MD, research officer

Finnish Cancer Registry, 00170 Helsinki, Finland

Lyly Teppo, MD, director

Correspondence to:

Dr Knekt.

BMF 1991;302:90
24)

\section{Serum cholesterol concentration and risk of primary brain tumours}

\author{
Paul|Knekt, Antti|Reunanen, Lyly Teppo
}

Several studies have reported raised serum cholesterol concentrations in patients with brain tumours. ${ }^{1-4} \mathrm{On}$ the other hand, a large number of studies have reported an inverse association between serum cholesterol concentration and risk of cancer at various other sites. ${ }^{5}$ The only cohort study of the relation between cholesterol and brain tumours examined relatively few patients. ${ }^{+}$We examined the possibility of an association in a larger cohort.

\section{Subjects, methods, and results}

During 1966-72, 48325 people (26001 men and 22324 women) aged $20-75$ years and apparently free of cancer participated in the Finnish Social Insurance Institution's mobile clinic health survey. Serum cholesterol concentration was determined at the initia visit and during follow up until 31 December 1984. In all, 72 people were diagnosed as having a brain tumour according to the Finnish Cancer Registry.5 Of these 44 had malignant tumours and 28 non-malignant tumours.

The mean age of those with brain tumours was 45.1 years, that of the rest of the subjects being 41.7 years. The age adjusted mean cholesterol concentration in those with malignant brain tumours was $6.54 \mathrm{mmol} / \mathrm{l}$ in men and $6.70 \mathrm{mmol} / \mathrm{l}$ in women The corresponding values in those without brain tumours were both $0.03 \mathrm{mmol} / \mathrm{l}$ lower (differences were not significant). In men with non-malignant tumours the mean concentration was $0.31 \mathrm{mmol} /$ lower and in women with non-malignant tumours it was $0.21 \mathrm{mmol} / \mathrm{l}$ higher than in those without tumours. These differences were also not significant.

Morbidity from brain tumours per million person years by tertiles of serum cholesterol concentration and relative risk ${ }^{\star}$ of brain tumours between highest and lowest tertiles

\begin{tabular}{|c|c|c|c|c|c|c|}
\hline & \multirow{2}{*}{$\begin{array}{l}\text { No of } \\
\text { cases }\end{array}$} & \multicolumn{3}{|c|}{ Serum cholesterol $(\mathrm{mmol} / \mathrm{l})$} & \multirow{2}{*}{$\begin{array}{l}\text { Relative } \\
\text { risk }\end{array}$} & \multirow{2}{*}{$\begin{array}{c}95 \% \\
\text { Confidence } \\
\text { interval }\end{array}$} \\
\hline & & $<5.95$ & $5 \cdot 95-7 \cdot 09$ & $\geqslant 7 \cdot 10$ & & \\
\hline \multicolumn{7}{|l|}{ Men: } \\
\hline All tumours & 42 & 110 & 157 & 112 & $1 \cdot 02$ & 0.45 to 2.31 \\
\hline Malignant tumours & 30 & 58 & 130 & 78 & $1 \cdot 36$ & 0.47 to 3.88 \\
\hline Non-malignant tumours & 12 & 54 & 27 & 35 & $0 \cdot 64$ & 0.17 to $2 \cdot 41$ \\
\hline \multicolumn{7}{|l|}{ Women: } \\
\hline All tumours & 30 & 104 & 73 & 101 & $0 \cdot 97$ & 0.39 to 2.41 \\
\hline Malignant tumours & 14 & 52 & 27 & 49 & 0.95 & 0.26 to 3.56 \\
\hline Non-malignant tumours & 16 & 51 & 49 & 52 & $1 \cdot 02$ & 0.28 to 3.66 \\
\hline \multicolumn{7}{|l|}{ Men and women: } \\
\hline All tumours & 72 & 110 & 117 & 101 & 0.93 & 0.50 to 1.69 \\
\hline Malignant tumours & 44 & 57 & 81 & 60 & $1 \cdot 05$ & 0.47 to 2.34 \\
\hline Non-malignant tumours & 28 & 53 & 37 & 41 & 0.78 & 0.31 to 1.94 \\
\hline
\end{tabular}

^Adjusted for age based on Cox's life table regression model.
The table gives the age adjusted morbidity associated with brain tumours by tertiles of serum cholesterol foncentration and the relative risks of brain tumours in the highest compared with the lowest tertile. The relative risk of a malignant or non-malignant brain tumour was 1.02 in men and 0.97 in women, which suggests there was no association between serum cholesterol concentration and the occurrence of brain tumours. The relative risk of a malignant tumour was higher $(1 \cdot 36)$ among men, but it did not differ significantly from unity. Further adjustment for body mass index and occupation did not notably alter the results; neither did exclusion of tumours occurring during the first two years of follow up, except in women with non-malignant tumours, in whom the association was strengthened, with the relative risk rising from 1.02 to 1.44 (95\% confidence interval 0.37 to $5 \cdot 64$ ).

\section{Comment}

We investigated the possibility of an association between serum cholesterol concentration and the incidence of malignant and non-malignant brain tumours in a large cohort with relatively high serum cholesterol concentrations. No notable association was found. Thus our study does not confirm the findings of previous studies. ${ }^{1-4}$

In the present cohort the mean serum cholesterol concentration was approximately $1.5 \mathrm{mmol} / \mathrm{l}$ higher than in the Whitehall population. ${ }^{4} \mathrm{~A}$ possible association between the presence of brain tumours and serum cholesterol concentration might, therefore, have been missed in our study if it existed only at low serum cholesterol concentrations, but this is unlikely. The possibility cannot be excluded that the results of the previous case-control studies may be artefactual because an existing brain tumour may have caused a spurious increase in the serum cholesterol concentration. ${ }^{1-3}$

In conclusion, our results, which are based on the largest population reported so far, do not support the conclusion that a high serum cholesterol concentration is a risk factor for brain tumours.

This study was partly funded by a grant from the Division of Cancer Prevention and Control, National Cancer Institute of the United States.

I Basu TK, Raven RW, Dickerson JWT, Williams DC. Vitamin A nutrition and its relationship with plasma cholesterol level in the patients with cancer. In F Vitam Nutr Res 1974;44:14-8.

2 Abramson ZH, Kark JD. Serum cholesterol and primary brain tumours: case-control study. Br f Cancer 1985;52:93-8.

3 Neugut AI, Fink DJ, Radin D. Serum cholesterol and primary brain tumours: a case-control study. Int f Epidemiol 1989;18:798-801.

4 Davey-Smith G, Shipley MJ. Plasma cholesterol concentration and primary brain tumours. BMF 1989;299:26-7.

5 Knekt P, Reunanen A, Aromaa A, et al. Serum cholesterol and risk of cancer in a cohort of 39000 men and women. 7 Clin Epidemiol 1988;41:519-30.

(Accepted 7 September 1990) 